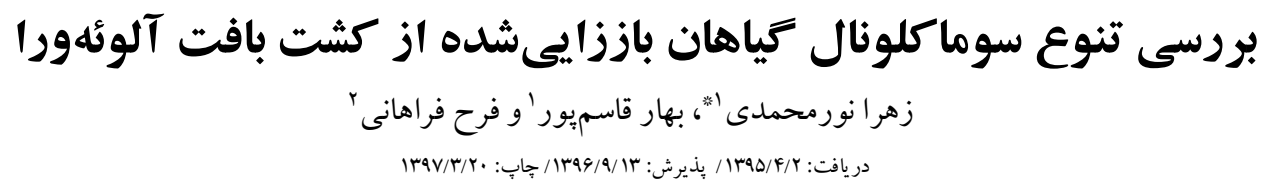

$$
\begin{aligned}
& \text { اكروه زيست شناسى، واحد علوم و تحقيقات، دانشگاه آزاد اسلامى، تهران، ايران }
\end{aligned}
$$

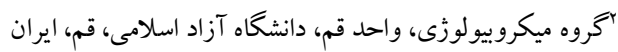

$$
\begin{aligned}
& \text { z-nouri@srbiau.ac.ir :مسئول مكاتبات و }
\end{aligned}
$$

جكيده. گياه . Aloe barbadensis Mill. ب. بعد barbadensis

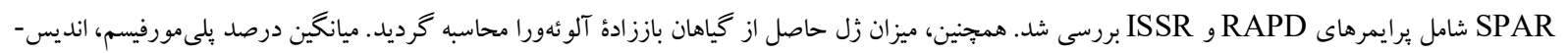

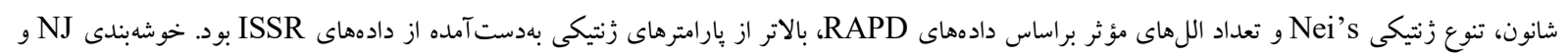

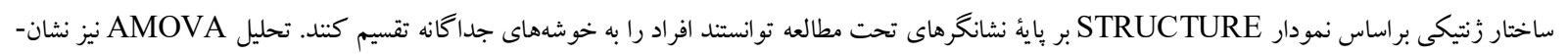

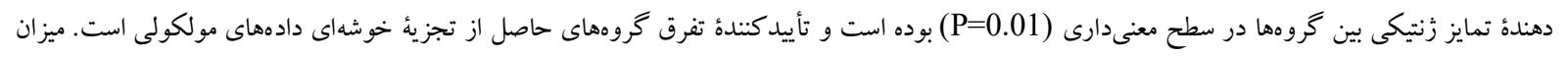

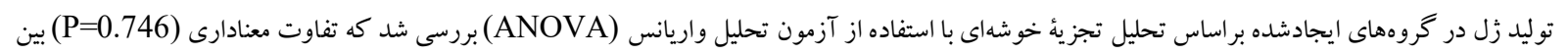

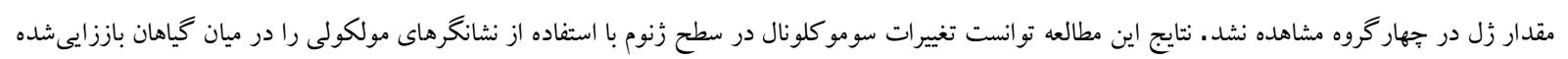

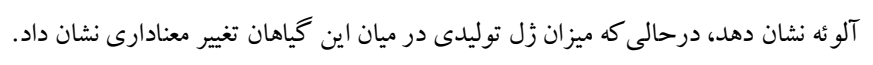

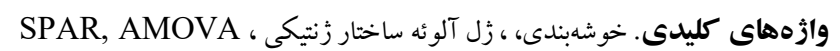

\title{
Somaclonal variation of tissue culture regenerated plants of Aloe barbadensis
}

\section{Mill.}

Zahra Noormohammadi ${ }^{*}$, Bahar Ghasempour ${ }^{1} \&$ Farah Farahani $^{2}$

Received 22.06.2016/Accepted 04.12.2017/ Published 10.06.2018

${ }^{1}$ Department of Biology, Science and Research Branch, Islamic Azad University, Tehran, Iran

${ }^{2}$ Department of Microbiology, Qom Branch, Islamic Azad University, Qom, Iran

*Correspondent author: z-nouri@srbiau.ac.ir

\begin{abstract}
Aloe barbadensis is a perennial, monocotyledonous, fleshy plant belonging to Aloaceae family. In this study, somoclonal variations of regenerated $A$. barbadensis plants were investigated. The plantlets of the forth subculture were transferred to soil for further study. The genomic DNAs of 40 regenerated plantlets were extracted and genetic variations were studied using SPAR markers including RAPD and ISSR primers. The amount of Aloe gel extracted from regenerated $A$. vera plants was also determined. The average percentage of polymorphism, Shannon index, Nei's genetic diversity and the number of effective alleles based on RAPD data were higher than genetic parameters obtained from ISSR data. NJ cluster and STRUCTURE plot based on molecular markers grouped regenerated plants into distinct clusters. AMOVA analysis also showed a significant $(\mathrm{P}=0.01)$ genetic distinction between the studied groups. This result also confirmed differentiation of regenerated plants. The amount of Aloe gel in the four groups (based on clustering method) was compared by using analysis of variance (ANOVA). The results showed no significant ( $\mathrm{P}=$ 0.746) differences among the amounts of gel in four groups. In total, our findings showed somaclonal variations on genomic level while no significant differences were observed in the amount of gel among regenerated Aloe plantlets.
\end{abstract}

Keywords. aloe gel, AMOVA, clustering, genetic structure, SPAR 
آلوئه است كه تأثيرات متفاوتى در ريزازديادى آنها داشته است.

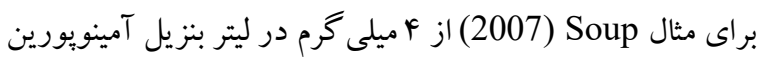
(BA) و اميلى گرم در ليترايندول استيك اسيد (IAA) استفاده 4mg-L BAP + كرد، در حالى كه تحقيقى ديخر استفاده از 0.2mg را براى تكثير بهتر آلوئه بيشنهاد

داده است (Nayanakantha et al., 2011). به هرحال، كشت بافت محصولات كثاورزى باعث ايجاد تنوع

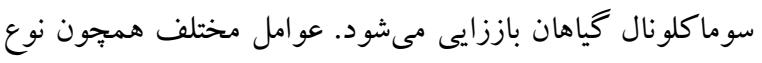

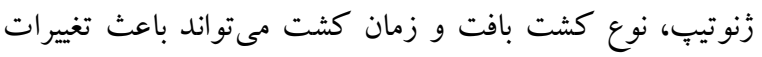

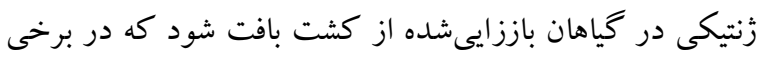

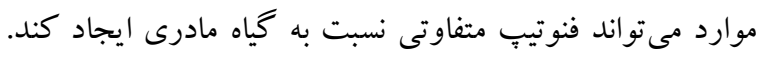
Haque و Ghosh (2013) طى مطالعات كاريوتييى و مولكولى فئي درباره گياهان باززايىشده رويش در مزرعه تفاوتى در اندازه و تعداد كروموزومها در تقسيم ميتوز و رفتار كروموزومى در تقسيم ميوز مشاهده نكردند.

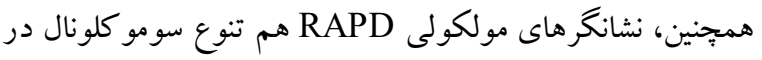

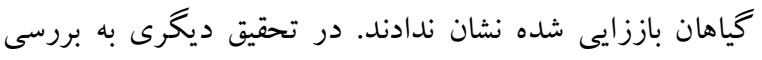

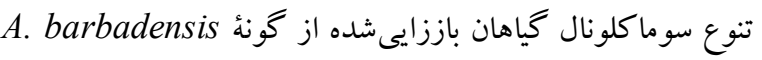

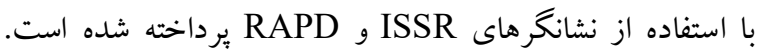

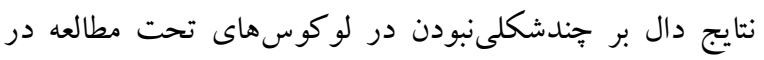
كياهان باززايىشده آلوئه بوده است (Sahoo \& Rout, 2014). اين درحالى است كه در تحقيق ديخرى درصد زيادى از

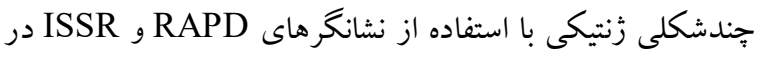

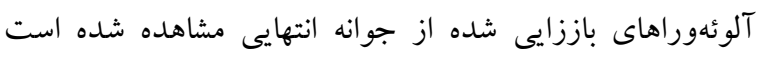

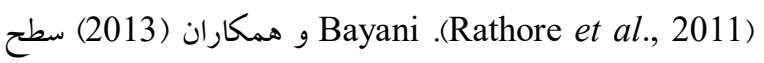

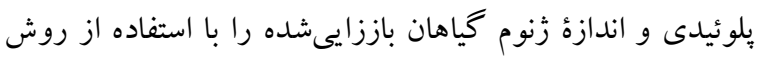

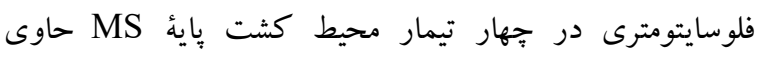

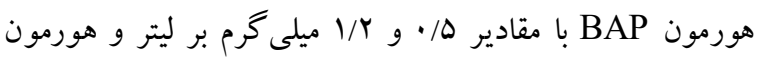

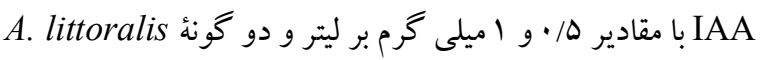
و A. barbadensis مقايسه كرد و تنوع سطح يلوئيدى و اندازه زنوم در گياهان باززايىشده را در تيمارهاى مختلف هورمونى

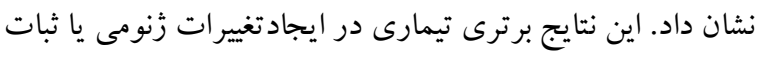
زنومى را نشان نداد. توليد تجارى خياه مورفولوزيكى از اهميت شايانى برخوردار است. بر اين اساس، طبق مطالعات گذشته، در تحقيق حاضر تنوع سوماكلونال كياهان
مقدمه

آلوئهورا، صبر زرد يا شاخ بزى با نام علمى A. vera L. مترادف گياهى گوشتدار barbadensis Mill. از راستهُ مارجوبهسانان، تيره سريشيان و سرده Aloe مهم ترين كونه سرده (Aloe barbadensis Mill.) vera L. Aloe هستند. بعضى كلونها دييلوئيد و برخى تتر إيلوئيد هستند و ايجاد

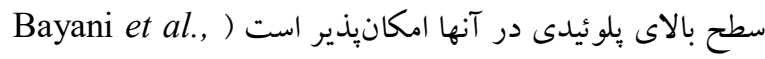
2013). بيش از . . F كونه از آلوئهورا در تمام نقاط جهان مى رويند (Mohammad, 2003) با وجود اين امروزه تنها دو گونه Aloe littoralis و Aloe barbadensis Mill. نامهاى Mill.

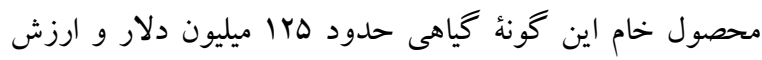
محصولات نهايى توليدشده آن بالغ بر ·11 ميليارد دلار است. در حال حاضر، محصولات مختلف آلوئهورا در صنايع مختلف غذايى (انواع نوشابهها، كميوت، دوغ و غيره)، صنايع آرايشى و بهداشتى (انواع كرمها، لوسيون، شاميوها، صابونها، شويندها) صنايع دارويى (كيسول، قرص جوشان) استفاده مىشود ( Mendonça et

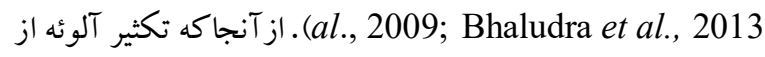
روشهاى مرتبط با بذر، به واسطة وجود نر عقيمى، راندمان يايينى دارد، يكانه راه كشت سنتى آلوئهورا تكثير از طريق باجوش است، اما سرعت تكثير آن بايين است، بهنحوى كه هر گياه بالغ در سال قادر به توليد تنها ب تا ^ يا جوش است كه اين تعداد جهت توليد تجارى اين گياه كافى نيست. بهدليل تقاضاى فراوانى كه براى صبر زرد در بازار داخلى و خارجى وجود دارد، اين گياه مورد توجه بسيارى از مراكز تحقيقاتى قرار گرفته است تا روش مناسبى جهت تكثير آنها يافت شود. ريزازديادى كياه از طريق كشت بافت يكى از روشهاى رايج در توليد اين نوع گياهان است كه بهطور گستردهايى دركانون توجه محققان قرار گرفته است. تحقيقات مختلفى در خصوص ريزازديادى گياه آلوئه تاكنون گزارش شده است. انتخاب نوع جدا كشت شامل جوانه جانبى يا راسى در ريزازديادى آلوئه يكى Supe, 2007; Hashemabadi \& ) از نكات مهم بوده است لوستى (Kaviani, 2008; Nayanakantha et al., 2011 ديخر، استفاده از فيتوهورمونها در كشت بافت گونههاى مختلف 
(OPA10, OPA11, OPA12, OPA13, OPA18 استفاده قرار گرفت. واكنش ISSR-PCR و RAPD-PCR در

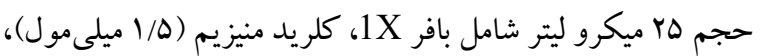

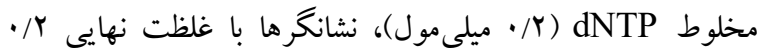

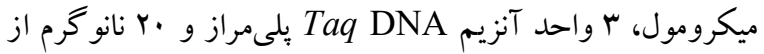

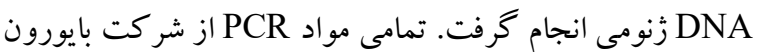
آلمان تهيه شد. واكنش تكثير در دستگاه ترموسيكلر (Techne،

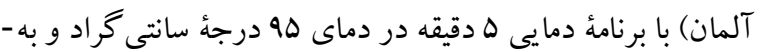
دنبال آن ·F سيكل در سه مرحله شامل ها ثانيه در دماى هو درجهُ سانتى گراد، ادقيقه در دماى •ه درجهُ سانتى گراد و •9 ثانيه در

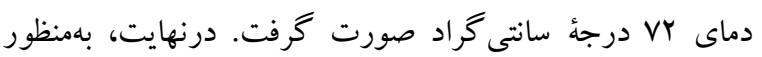

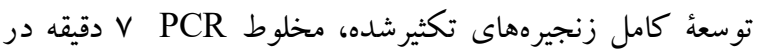

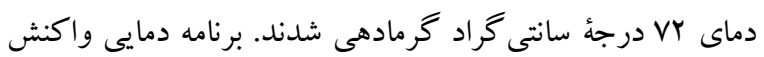

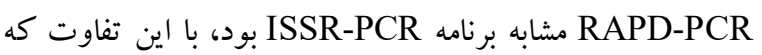

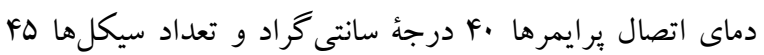

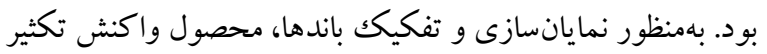

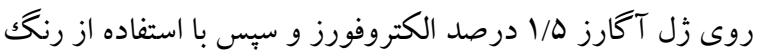

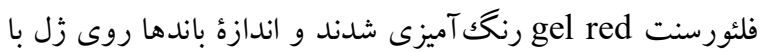

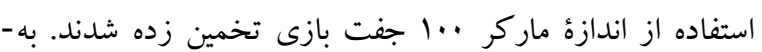

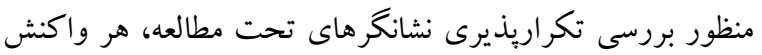

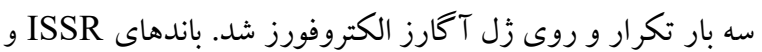

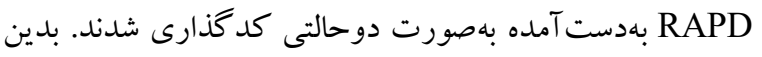

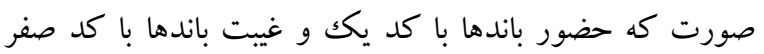

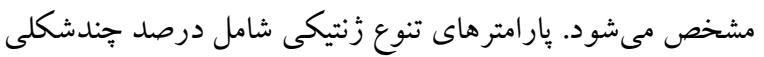

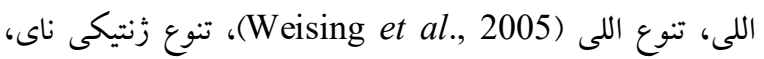

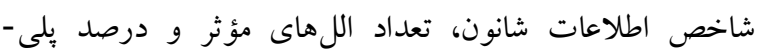
Freeland et al., 2011; Weising et al., ) مورفيسم است دوصنائل .2005 گروهبندى گياهان باززايىشده و مادرى از بوت استرٍ كردن

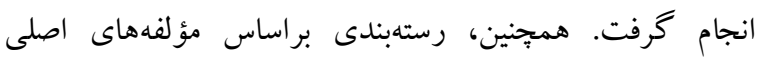
(PCoA) (http://darwin.cirad.fr/)

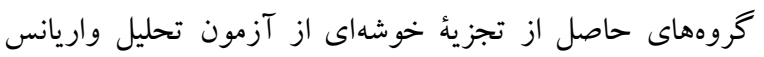

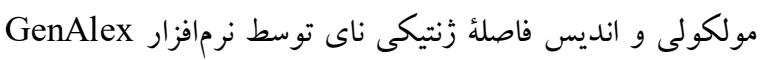
نسخه 6.5 انجام گرفت (Peakall \& Smouse, 2006). تحليل
باززايىشده A barbadensis و ساختار زنتيكى آنها بعد از جهار واكشت و انتقال آنها به خاك تحت بررسى قرار گرفت. از

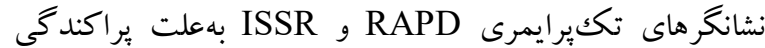

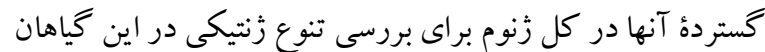

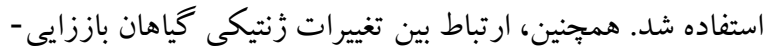

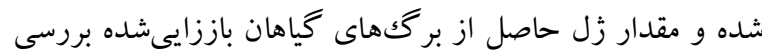
شد.

\section{مواد و روشها}

كشت بافت

كياه آلوئهورا از شر كت سبز گستر تهيه و با حذف بر گكها، ساقه به اندازههاى 1/1-1 سانتى متر در محلول ضدعفونى كننده به مدت

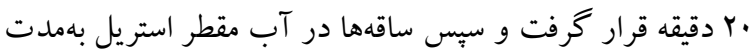
MS (Murashige - يك ساعت نخهدارى شد. محيط كشت

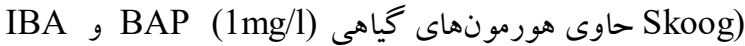
(0.5mg/l) فوق منتقل شد و در اتاق رشد با دماى ها درجهُ سانتى گراد و فتويريود 19/1 قرار گرفت. گياهان باززايىشده تا جهار واكشت دانت

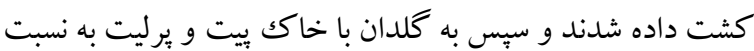

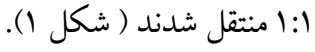

\section{استخراج DNA و ارزيابى קندشكلىهاى نشانكرهاى \\ ISSR RAPD}

F. نمونة گياه باززايىشده در واكشت جهارم و منتقلشده در

خاكى براى •الوكوس نشانگر RAPD و •الو كوس نشانگر

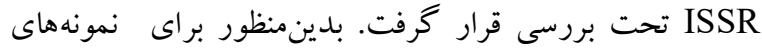

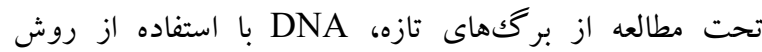
تغييريافته CTAB توسط Križman و همكاران (2006) بان

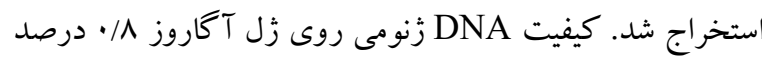

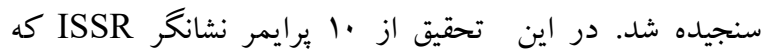
دانشگاه بريتيش كلمبياى كانادا معرفى كرده است استفاده شد. اين اين يرايمرها شامل: UBC823، UBA)، (GA)، (GA)، و UBC834، UBC849، UBC 810 UBC 807 UBC 811 هستند. يُرايمر هاى نشانگر هاى RAPD (GA) سرى A كه توالىهاى آنرا شركت إيرون تكنولوزى آمريكا ارائه OPA02, OPA03, OPA04, OPA05, OPA09, ) داده است 


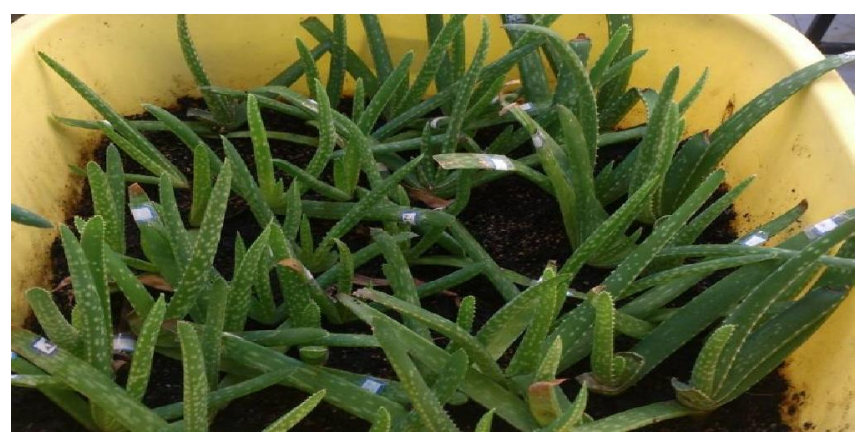

شكل 1 - گياهان باززايىشده واكشت جهارم در خاك يّت و يرليت.

Fig. 1. Fourth sub-cultured regenerated plants transferred into pitte and perlite soil.

الكوى نواربندى برايمرهاى يكى از نشانكرهاى ISSR و آنداى RAPD

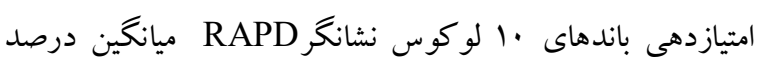

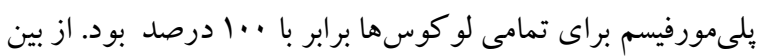

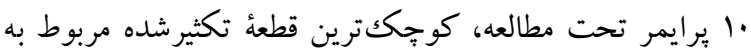

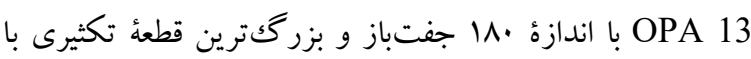

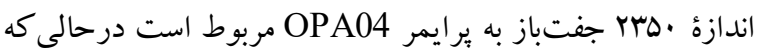

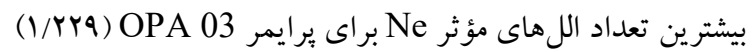

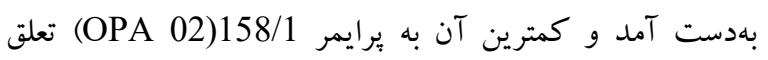

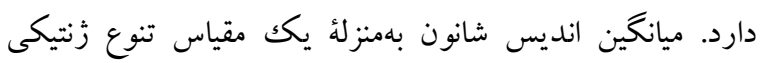

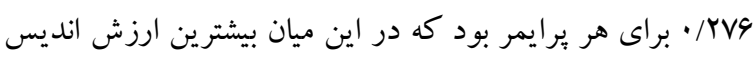

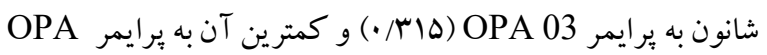

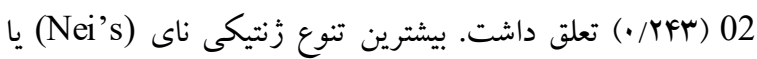

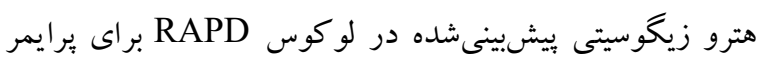

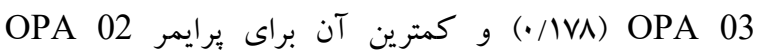

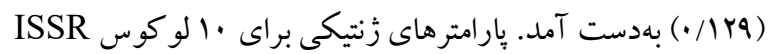

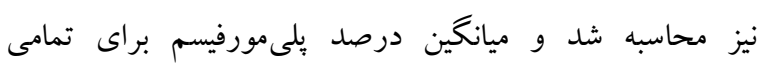

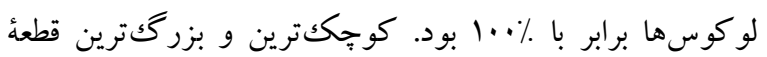

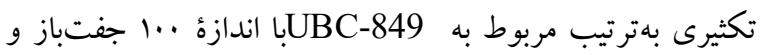

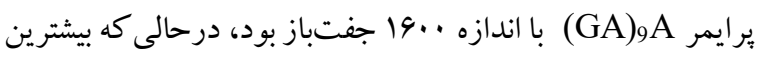

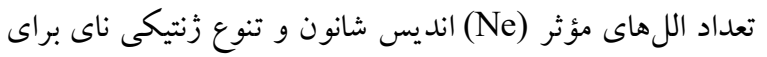

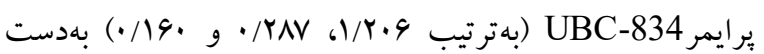
آمد و كمترين آنها به קرايمر (CA)

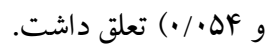

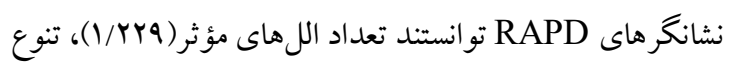

روى نمونههاى تحت مطالعه با كمكك نرمافزار STRUCTURE STRUCTURE نسخه 2.2 انجام شد (Falush et al. 2007). در اين روش، ابتدا K خوشه در نظر كرفته مىشود كه هر كدام از آن خوشهها بهوسيلة فر كانس الل هاى هر لو كوس از يتد يكديخر متمايز مىشوند (Pritchard et al., 2000). استخراج ذل كياه آلوئهورا

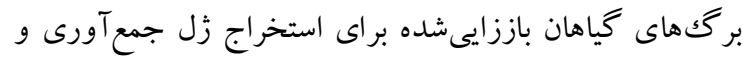

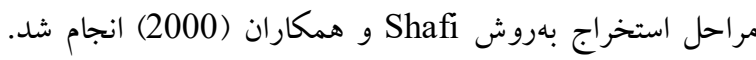

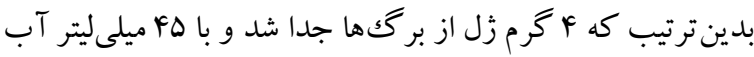

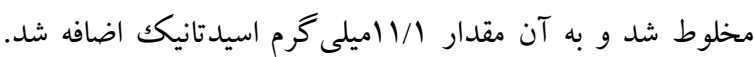

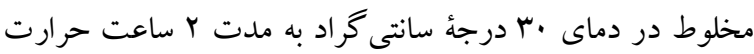

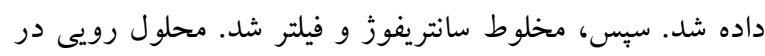

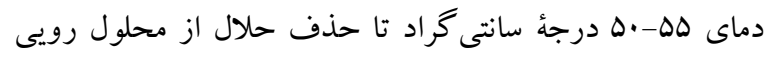

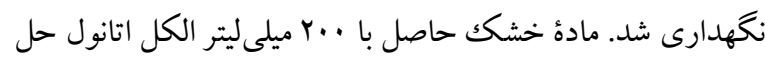

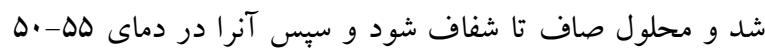

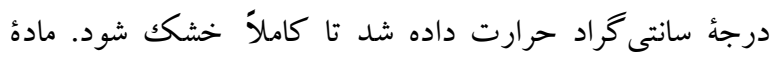

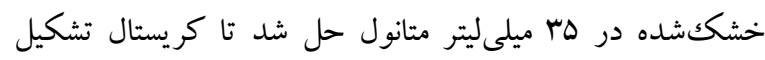

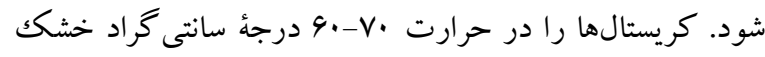

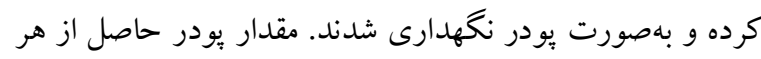

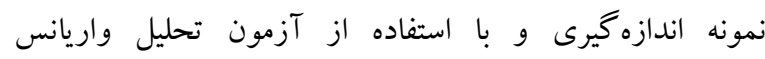
تفاوت ميانگين بين گروههاى تحت مطالعه در سطح معنى دارى ه • • تحت مطالعه قرار گرفت.

نتايج ارزيابى تنوع زنتيكى 
جدول ا- بارامترهاى زنتيكى نشانغرهاى مولكولى تحت مطالعه در گياهان باززايىشده آلوئهورا.

Table 1. Genetic parameters of used molecular markers in regenerated Aleo vera plants.

\begin{tabular}{|c|c|c|c|c|c|}
\hline نشانخر مولكولى & $\begin{array}{l}\text { تعداد اللهاى مؤثر } \\
\text { (Ne) }\end{array}$ & تنوع زنتيكى ناى (He) & (I) نديس شانون & درصد بليمورفيسم & باندهاى اختصاصى \\
\hline RAPD & $1 /$ rYq & . / V V & - / YVQ & 1.. & v \\
\hline ISSR & $1 / r \cdot 9$ & .199. & rוl & 1.. & 9 \\
\hline
\end{tabular}

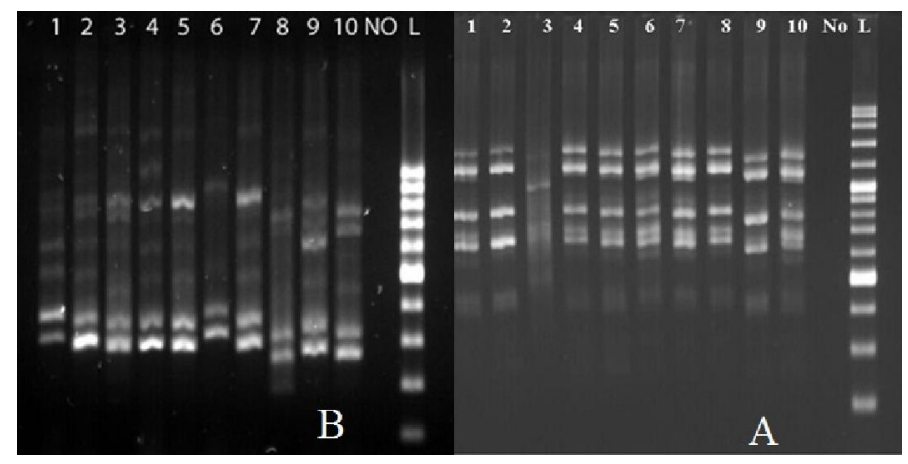

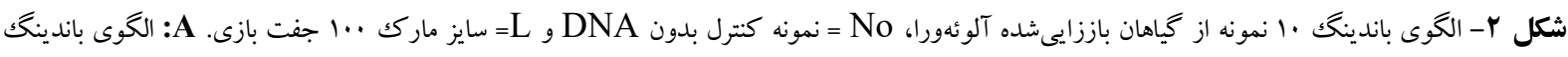

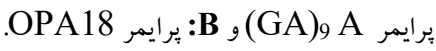

Fig. 2. Banding profile of 10 regenerated Aloe vera plants. $\mathrm{No}=$ no $\mathrm{DNA}, \mathrm{L}=100 \mathrm{bp}$ ladder. A: $(\mathrm{GA})_{9} \mathrm{~A}$ banding profile, B: OPA18 banding profile.

هم Rمبتخى در سطح معنى دارى را نشان داد

كه نمايانگر هميوشانى بين دو ماتريس تشابه نشانخرهاى RAPD

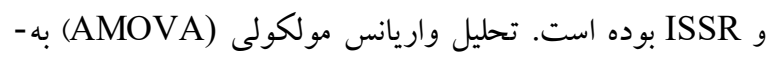

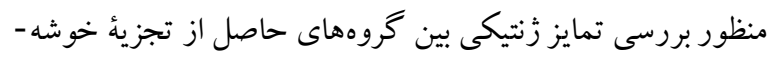

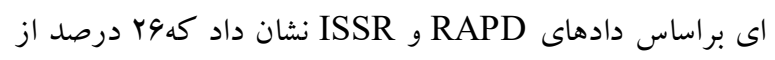

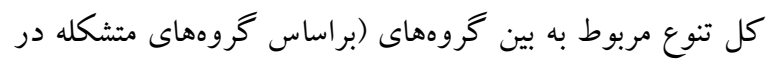

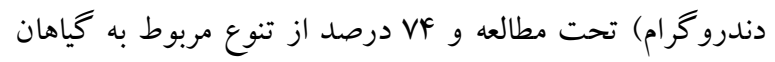
درون يك گروه بوده است (جدول Y). در كل اين آزمون نشانكر

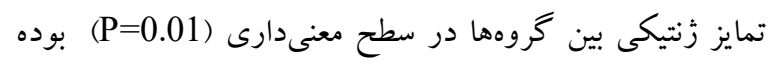

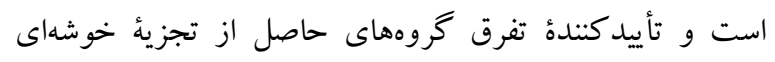

$$
\text { دادههاى مولكولى است. }
$$

تحليل ساختار زنتيكى با استفاده از روش

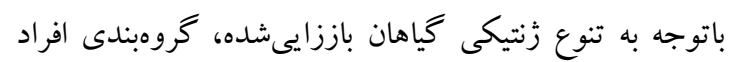
مطالعشده را با تحليل STRUCTURE با بيروى از آزمون

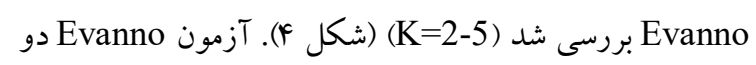

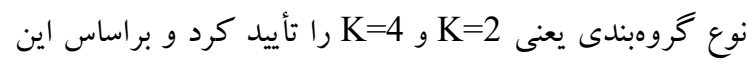

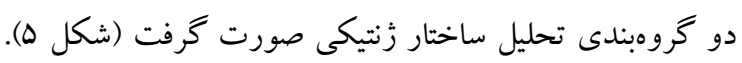

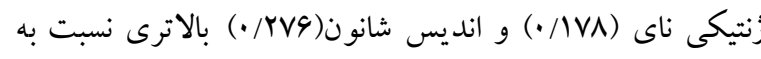
نشانخر ديخر ISSR نشان دهند (جدول آ ).

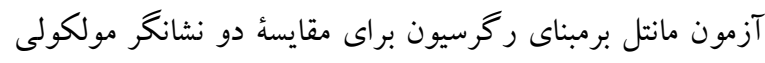

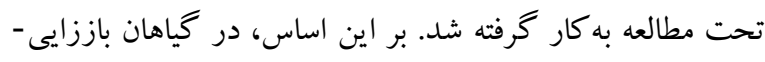

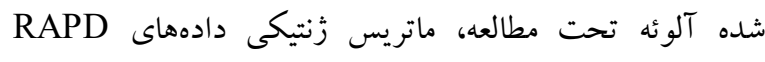

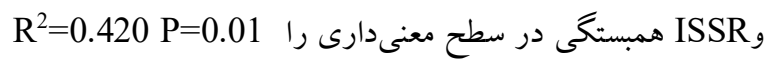

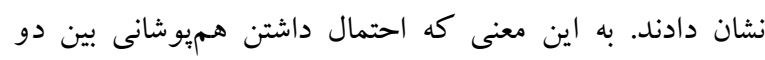
نشانكر RAPD و ISSR بسيار زياد است. تجزيؤ خوشهاى كياهان باززايع شده از كشت بافت آلوئه

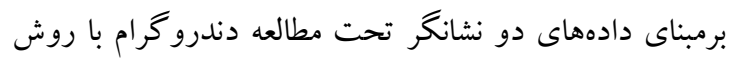

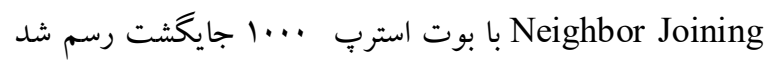

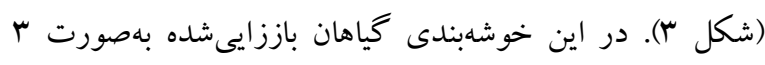

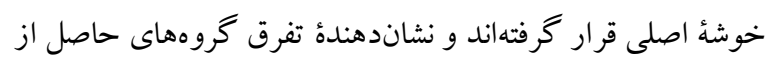

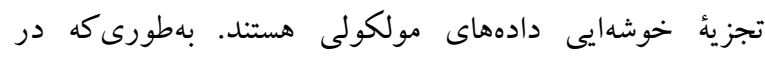
دندرو گرام اختصاصى هر كدام از نشانگرهاى تحت مطالعه نيز

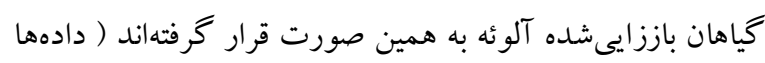
ارائه نشده است).آزمون مانتل حاصل از دادههاى دو نشانه بـانهر 


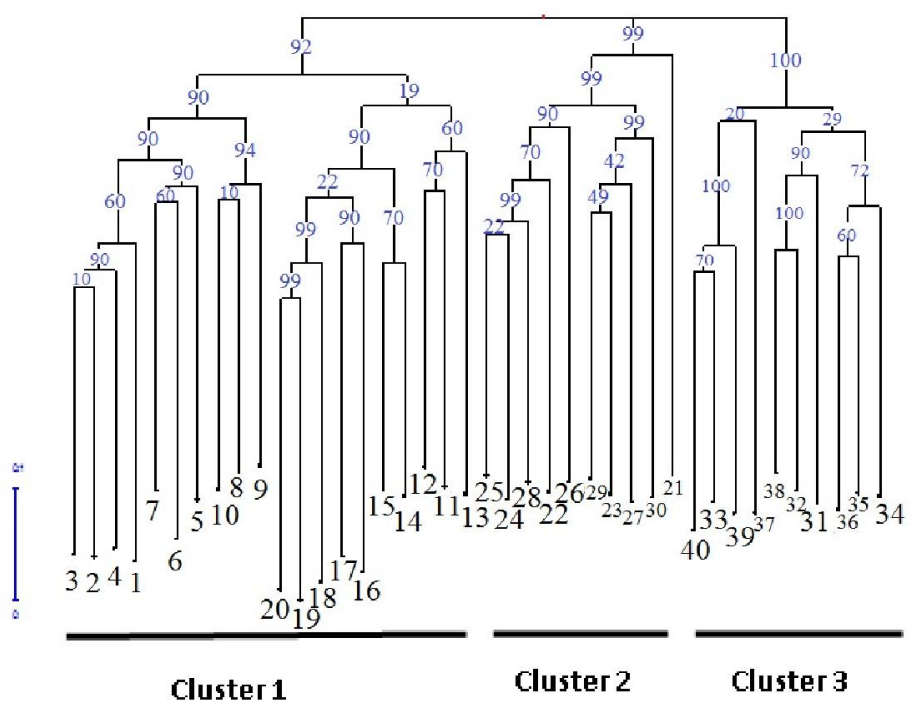

$$
\text { شكل r- دندرو كرام NJ تركيب دو نشانكر ISSR و RAPD و }
$$

Fig. 3. NJ dendrogram based on combined RAPD and ISSR data.

$$
\text { جدول r- تحليل واريانس مولكولى براساس دادههاى RSR و RAPD براساس سه كروه حاصل از تجزية خوشهاى. }
$$

\begin{tabular}{|c|c|c|c|c|c|}
\hline & درجهُ & مجموع & ميانغين & واريانس & \\
\hline & آزادى & مربعات & مربعات & تخمينى & درصد تنوع \\
\hline بين گروهى & $r$ & rir,r. & $v \cdot, v q$ & $\Delta, \Delta$ & rq \\
\hline درون گروهى & rq & $\Delta q V, \cdot \cdot$ & $10, v \Delta$ & $10, v \Delta$ & $v^{f}$ \\
\hline مجموع & ra & Wa,r. & ؟؟ & $r 1, r_{\Delta}$ & $1 .$. \\
\hline
\end{tabular}

Table 2. Analysis of molecular variance based on RAPD and ISSR data on three groups formed by cluster analysis.

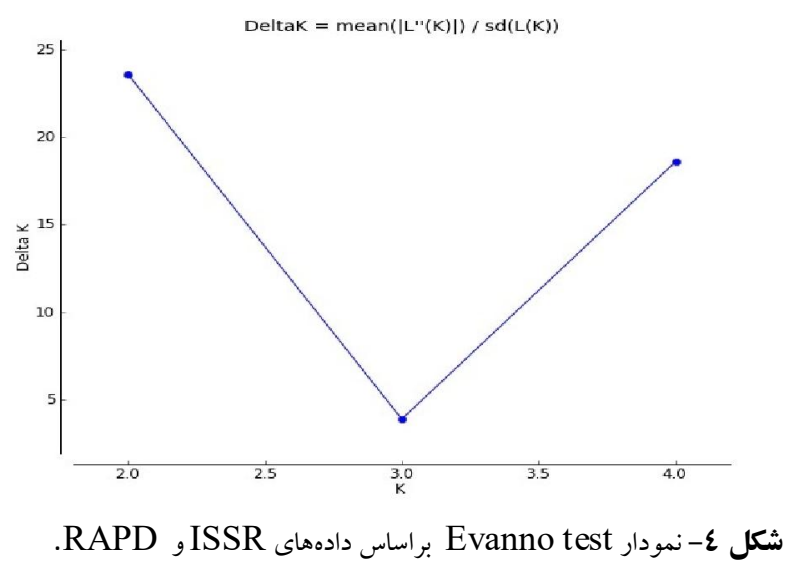

Fig. 4. Evanno test plot based on ISSR and RAPD data. 


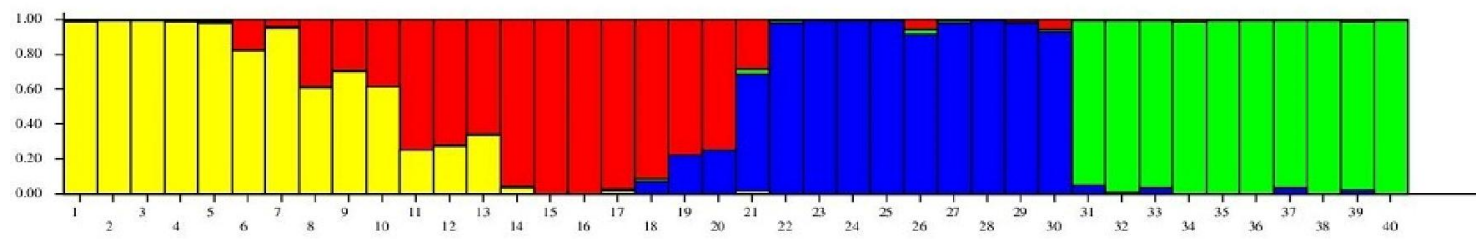

$\mathbf{k}=\mathbf{4}$

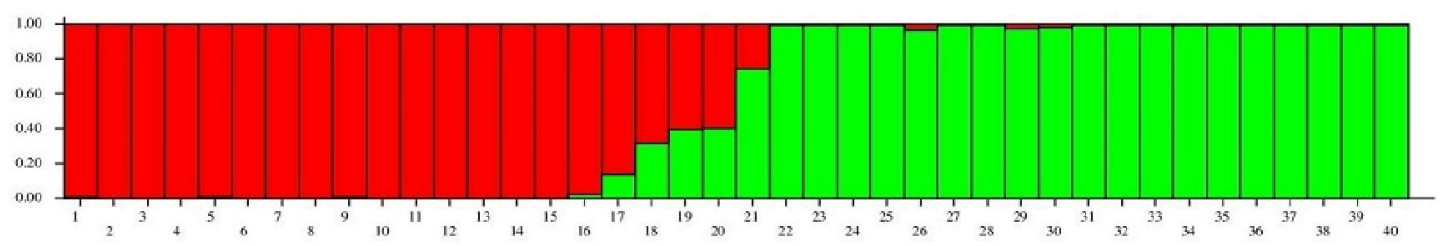

$\mathbf{k}=\mathbf{2}$

شكل 0- ساختار زنتيكى گروههاى تحت مطالعه براساس دادههاى ISSR و وSTR استفاده از تحليل STRUCTURE.

Fig. 5. Genetic structure of studied groups based on ISSR and RAPD dada using STRUCTURE analysis.

تحليل واريانس، تفاوت معنادارى بين مقدار زل در جهارگروه مشاهده نشد (P=0.746). تحليل مقايسٔ ميانخينها بهمنظور مقايسُٔ دو به دو گروهها نيز تفاو تى را نشان نداد.

بحث توليد گياهان حاصل از كشت بافت يكى از راههاى مدرن در توليد انبوه در كشاورزى جديد است. بررسى تغييرات زنتيكى سوماكلونال يكى از دغدغههاى محققان در اين صنعت است. تحقيق حاضر به بررسى تنوع زنتيكى گياهان باززايىشده در واكشت جهارم با استفاده از نشانگر هاى مولكولى مبتنى بر DNA يرداخته است. نتايج حاضر نشاندهنده تنوع بالا در ميان كياهان باززايىشده آلوئهورا در هر دو نوع نشانكر است. كفتنى است دو نشانكر تحت مطالعه بهطور كسترده در زنوم براكنده هستند و مى توانند تصوير واضحترى از تغييرات زُنتيكى حاصل از كشت بافت را ارائه دهند. ازطرف ديخر، در اين ميان نشانكرهاى RAPD تنوع زنتيكى بيشترى را نسبت به نشانگرهاى ISSR در اين گياهان ارائه داده است. بهنظر مىرسد مىتوان نشانكر هاى RAPD تحت مطالعه را بهمثابة نشانكر برتر در بررسى تنوع سوماكلونال گياه

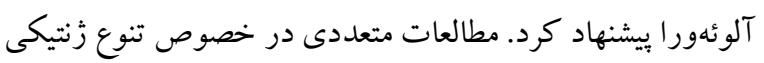
در گياهان باززايىشده آلوئه در محيطهاى مختلف كشت و نيز انواع جداكشتهاى اين گياه در واكشتهاى مختلف صورت
جزئيات نقشة STRUCTURE درجاتى از مبادلهُ زنى بين گرووهها را نشان ميدهد. تركيب اللى گروه اول (ا الى •) (قطعات زرد)، اختصاصى و با بقيه متفاوت است. با اين حال، بخشهاى

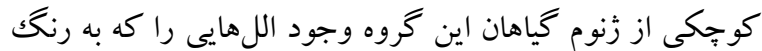
ديخرى (رنخك قرمز) هستند را نشان مىدهد كه اين الل فر كانس بالايى را در گرووه دوم (ll الى ·r) نشان مىدهد. در همين گرووه فر كانس پياينى از الل عمده موجود در گروه ديخر (رنگك آبى) را در برخى از گياهان خود نشان مىدهد كه حاكىاز نوار آرايى اللى در اين كروههاست. نكتئ جالب توجه اين است كه افراد اس تا · F فر كانس اللى غالب (رنگك سبز) را در تمامى افراد نشان مىدهد و الل نوتر كيب (رنگ آبى) با فر كانس الل خيلى كم در برخى افراد اين كروه مشاهده مىشود. اين گروه اخير در تجزية خوشهاى نيز

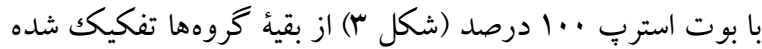
است كه اين موضوع تأييد كنندهُ تركيب اللى اختصاصى اين افراد

\section{استخراج ذل از كياهان باززايیشدهُ آلوئهورا} بهنظور مقايسٔ ميزان توليد زل در خياهان باززايى شدهُ آلوئه SJ مياهان را براساس گروهبندى حاصل از تجزئ خوشهاى براساس دادههاى دو نشانگر مولكولى، به جهار گرووه تقسيم و ميزان توليد زل در اين جهار گروه با استفاده از آزمون تحليل واريانس (ANOVA) و مقايسٔ ميانگينها بررسى شد. براساس 
ميان زرم بلاسم مىتواند منبع تنوع زُنتيكى در كشت بافت باشد Bhaludra et al., 2013; Lal et al., 2002; Nejatzadeh-) - Barandozi et al., 2012 شده در اين تحقيق اندازهيرى شد. تحقيقات نشان داده است

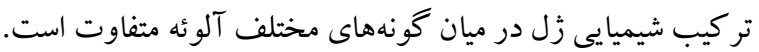

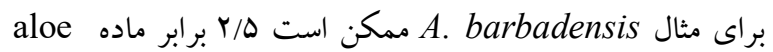

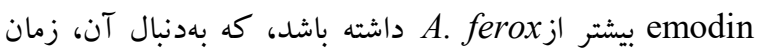

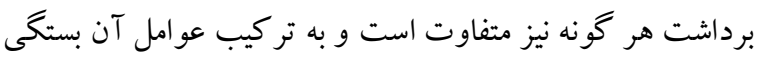

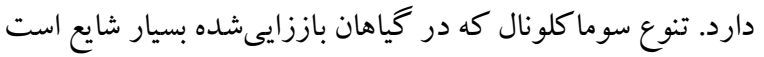

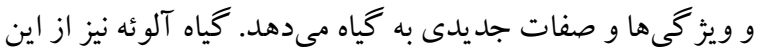
قاعده مستثنى نيست و طى تحقيقى كه و و و و و همكارانش

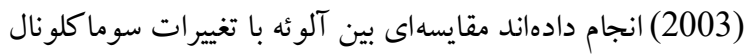

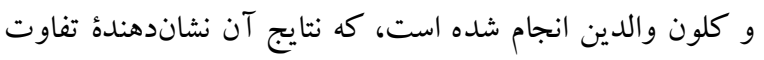
تر كيبات موجود در زل و مقدار آن است. در تحقيق ديخرى Saggoo و Kaur (2010) از جداكشت ساقهُ آلوئه ورا دو رقم HPM1 و Pند دBL3 در محيط كثت

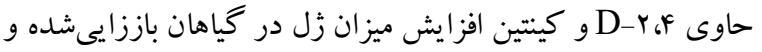

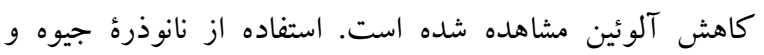
NH4NO3 Nano-Tio2 توانيى افزايش ماده آلوئن را تا KA ساعت بعد در كالوسهاى ايجادشده نشان داده است (Raei et al., 2014). در تحقيق حاضر، ميزان زل تفاوت معنىدارى در بين گياهان

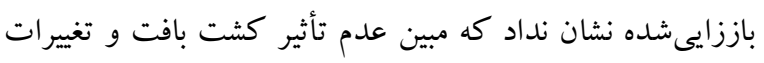
زرنتيكى حاصل در زنهاى دخيل در توليد زل در اين گياهان است.

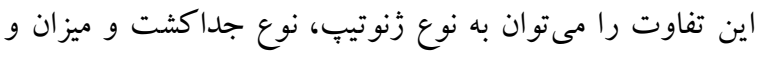

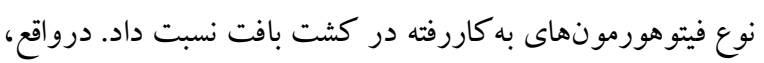

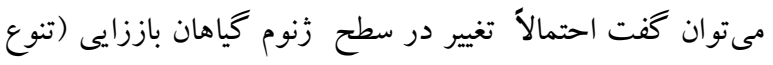

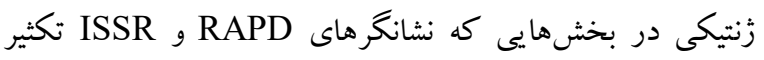
كردهاند) روى زنهاى توليد كندهُ زل نبوده است يا ينائ اين تغييرات

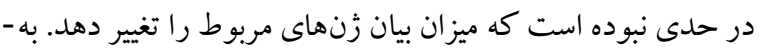
هرحال تحقيقات بيشتر و بررسى زنهاى دخيل در مسير توليد زل

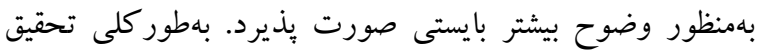

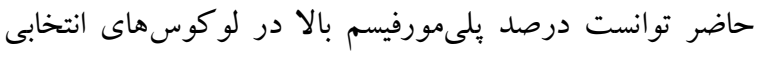

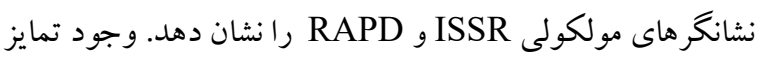

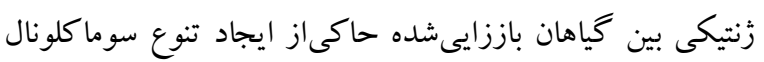

كرفته است. برخى از اين گزارش ها عدم تنوع زُنتيكى را با استفاده

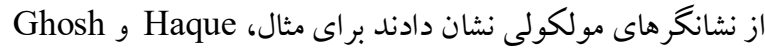
(2013) طى مطالعات مولكولى گياهان باززايىشده از ساقؤ آلوئه ورا تا سه واكشت و دو سال رويش در مزرعه تنوع سوما كلونال را در گياهان باززايىشده مشاهده نكردند. گياهان باززايىشده از

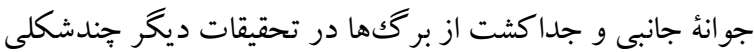

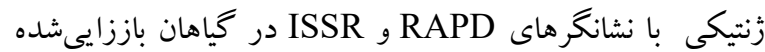
Hashemabadi \& Kaviani 2008; ) نشان داده نشده است باني Gantait et al., 2010; Rathore et al., 2011; Sahoo \& Rout 2014 (اين درحالى است كه گياهان باززايىشده از محور كل آذين از كالوس تا حدود •N درصد بلىمورفيسم را نشان دادند (Rathore et al., 2011) . (Rayani و همكاران (2013) با بررسى واكثتهاى مختلف حاصل از كشت بافت جوانه انتهايى

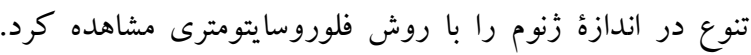

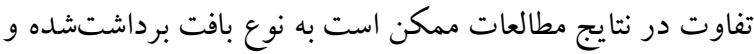
كشت مورد استفاده مرتبط باشد. همانكونه كه ذكر شد، در بالهر تحقيق حاضر از كشت قسمت انتهايى ساقه آلوئه استفاده شد و يلى مورفيسم بالايى (..1 درصد) در هر دو نوع نشانگر مشاهده شد. بمنظور بررسى ساختار زنتيكى جداكشتهاى باززايىشده در

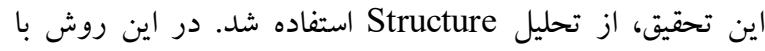
استفاده از تكرار تصادفى دادهها و محاسبة Likelihood مىتوان به اطلاعات دقيقترى دربارهٔ ميزان تنوع نمونههاى تحت مطالعه و قرابت ميان نمونهها دست يافت. اين روش يكك روش مدلدار

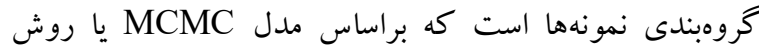

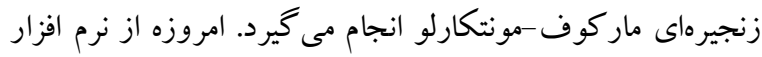
STRUCTURE منطقه هيبريدها، افراد هيبريد و نيز تعلق افراد به جمعيتها استفاده

در تحقيقات بهعمل آمده درباره گياهان باززايىشده آلوئهورا

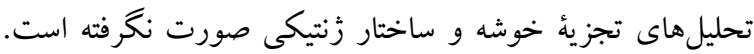

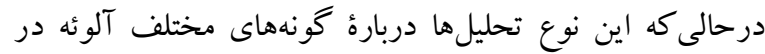

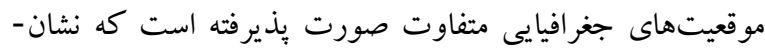

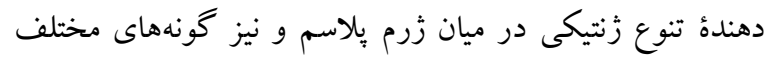

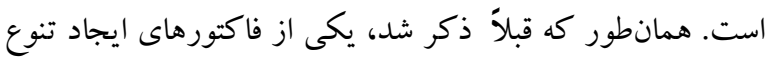

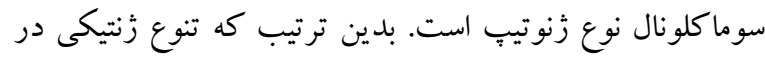




\section{REFERENCES}

Bayani, A., Noormohammadi, Z., Farahani, F. and Nejadsatari, S. 2013. The study of morphological and cytogenetical variations in Aloe littoralis and Aloe barbadensis regenerated plants. M.Sc. Thesis, Science and Research Branch, Islamic Azad University, Tehran, Iran.

Bhaludra, C.S.S., Bethapudi, R. R., Murugulla, A.C., Pullagummi, C., Latha, T., Venkatesh, K., Bheemagani, A.J., Pudutha, A., and Rani, A.R. 2013. Cultivation, phytochemical studies, biological activeities and medicinal uses of Aloe ferox, grandfather of Aloes an important amazing medi-cinal plant. - Int. J. Pharmacol. 9: 405-415.

Ferro, C.P.V.A., Bradbury, F., Shakir, E., Rahman, S.R. and Stimon, W.H. 2003. In vitro susceptibilities of Shigella flexneri and Streptococcus pyogenes to inner gel of Aloe barbadensis Miller. antimicrob. Agents Chemotherap. 47: 1137-1139.

Freeland, J.R., Kirk, H. and Peterson, S.D. 2011. Molecular ecology ( $2^{\text {nd }}$ ed). UK: Wiley-Blackwell, pp: 449.

Gantait, S., Mandal, N., Bhattacharyya, S. and Das P.K. 2010. A novel strategy for in vitro conservation of Aloe vera $\mathrm{L}$. through long term shoot culture. Biotechnol. 9: 326-331.

Haque, M.S. and Ghosh, B. 2013. High frequency microcloning of Aloe vera and their true-to-type conformity by molecular cytogenetic assessment of two years old field growing regenerated plants. - Bot. Studies 54: 1-10. doi: 10.1186/1999-3110-54-46.

Hashemabadi, D. and Kaviani, B. 2008. Rapid micropropagtion of Aloe vera shoot multiplication. - Afr. J. Biotechnol. 72: 64-78.

Krizman, M., Jakse, J., Baricevic, D., Javornik, B. and Mirko, P. 2006. Robust CTAB-activated charcoal protocol for plant DNA extraction. - Actaagri Slov. 87: 427 - 433.

Lal, R.K., Sharma, J.R., Patra, D.D., Farooqui, A.H.A. Kalra, A., Baba, J.R., Singh, A.K. and Khanuja, S.P.S. 2002. Aloe vera and its cultivation in India. Farm bulletin, central institute of medicinal and aromatic Plants, Lucknow, India. 54: 124-134.

Mendonça, F.A., Passarini Junior, J.R., Esquisatto, M.A., Mendonça, J.S., Franchini, C.C. and Santos, G.M. 2009. Effects of the application of Aloe vera L. and micro current on the healing of wounds surgically induced in wistar rats. - Acta Cir. Bras. 24: 150-155.

Mohammad, A. 2003. Aloe vera. - Textbook of pharmacognosy pp: 111-115.

Nayanakantha, N., Singh, B. and Kumar, A. 2011. Improved culture medium for micropropagation of Aloe vera L. - Trop. Agri. Res. Exten. 13: 87-93.

Nejatzadeh-Barandozi, F., Naghavi, M.R., Hassani, M.E., Mostofi, Y., Mousavi A. and Tahmasebi Enferadi S. 2012. Diversity of Iranian Aloe (Aloe vera L.) genotypes based on aloenin contents and some morphological traits. - J. Hortic. Sci. Biotechnol. 87: 673-677.

Peakall, R. and Smouse, P.E. 2006. GENALEX 6: genet-

$$
\begin{aligned}
& \text { در كياهان باززايىشده واكشت جهارم و منتقل شده به خاكك است. } \\
& \text { بر اين اساس، به نظر مىرسد اين گياهان براى توليد انبوه زُنوتيب } \\
& \text { خاص براى دستيابى گياهان مشابه با گياه مادرى مناسب نيست، } \\
& \text { درحالى كه اين روش در بلنزادى گياهان به منظور رسيدن به } \\
& \text { صفات مطلوب در برنامههاى زاد آورى كاربرد خو اهد داشت. } \\
& \text { سياسگز ارى } \\
& \text { نويسند كان مقاله از واحد علوم و تحقيقات، دانشگًاه آزاد اسلامى } \\
& \text { به دليل در اختيار قرار دادن امكانات آزمايشگاهى قدردانى مى لى } \\
& \text { نمايند. }
\end{aligned}
$$


-ic analysis in excel. Population genetic software for teaching and research. - Mol. Ecol. Not. 6: 288-295.

Pritchard, J.K., Stephens, M. and Donnelly, P. 2000. Inference of population structure using multilocus genotype Data. - Genetics 155: 945-959.

Raei, M., Angaji, S.A., Omidi, M., and Khodayari, M. 2014. Effect of abiotic elicitors on tissue culture of Aloe vera. - Intl. J. Biosci. 5: 74-81.

Rathore, M.S., Chikara J, Mastan, S.G., Rahman, H., Anand, K.G. and Shekhawat N.S. 2011. Assessment of genetic stability and instability of tissue culture propagated plantlets of Aloe vera L. by RAPD and ISSR markers. - Appl. Biochem. Biotechnol. 165: 1356-65.

Saggoo, M.I.S. and Kaur, R. 2010. Somaclonal variation in plants regenerated from cultures of two morphologically distinct accessions of Aloe vera L. Annals Biol. Res. 1: 172-177

Sahoo, S. and Rout, G.R. 2014. Plant regeneration from leaf explants of Aloe barbadensis Mill. and genetic fidelity assessment through DNA markers. - Physiol. Mol. Biol. Plants 20: 235-240

Shafi, K., Khan, L. and Khan, A. 2000. Commercial extraction of gel from Aloe vera L. leaves. - J. Chem. Sci. Pak. 22: 47-49.

Supe, U.J. 2007. In vitro regeneration of Aloe barbadensis. - Biotech. 6: 601-603

Weising, K., Nybom, H., Wolff, K. and Kahl, G. 2005. DNA fingerprinting in plants. principles, methods, and applications. ( $2^{\text {nd }}$ ed.), Boca Rayton, Fl., USA: CRC Press, pp: 472.

$* * * * *$

How to cite this article:

Noormohammadi, Z., Ghasempour, B. and Farahani, F. 2018. Somaclonal variation of tissue culture regenerated plants of Aloe barbadensis Mill. - Nova Biologica Rep. 5: $72-81$.

نورمحمدى، ز.، قاسميور، ب. و فراهانى، ف. لو إ. بررسى تنوع

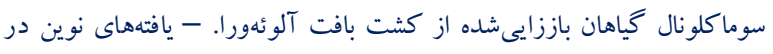

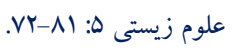

